\title{
CHAIRMAN MILLER, THE FEDERAL TRADE COMMISSION, ECONOMICS, AND RASHOMON
}

\author{
Eleanor M. Fox* \\ INTRODUCTION
}

In 1981, President Reagan appointed James C. Miller, III, to head the Federal Trade Commission (FTC). Mr. Miller was the first economist to hold this position; all prior FTC Chairmen had been attorneys. And, since one of Mr. Miller's roles as chairman was that of a jurist, he joined the ranks of "economically sophisticated judges." This article examines Mr. Miller's contributions as an economically sophisticated judge. This article is not about Mr. Miller as economist and jurist in a vacuum, however; on the contrary, it is about economics and Rashomon. ${ }^{2}$

Miller's role as Commissioner and Chairman of the FTC differs from the role of a federal judge. A commissioner of the Federal Trade Commission serves the combined functions of executive (prosecutor), legislator (rule maker and policy maker), and jurist. The FTC decides what complaints should be brought, ${ }^{3}$ what appeals should be taken, and when writs of certiorari should be sought. As a judicial body it sits in judgment on appeals from decisions of the FTC's administrative law judges. As an administrative body it promulgates rules by which, as a judicial body, it has the power to compel compliance. ${ }^{4}$ The Chairman of the FTC has additional external and internal roles. The Chairman sets the tone for the Commission. He sets

Copyright (C) 1988 by Law and Contemporary Problems

* Professor of Law, New York University School of Law.

1. I use this phrase with some trepidation, for "economically sophisticated judge" is a term often reserved for the jurist who believes in the primacy of efficiency over other values that may inform law, and even then it is often reserved for individuals who hold strong beliefs in the robustness of the free market and the clumsiness and perversity of government intervention. Thus, Judges Bork, Easterbrook, Posner, and other individuals who associate themselves with the Chicago School would be on the top of most lists. Yet, many other jurists who do not fit this mold probably understood economics equally as well. I would count among them Judge Learned Hand and Judge Charles Wyzanski.

2. R. Akutagawa, Rashomon And Other Stories 8 (G.W. Shaw trans. 1964); Rashomon (RKO Radio Pictures 1951) (motion picture based on the short stories Yabu no Naka and Rashomon by $\mathbf{R}$. Akutagawa); F. Kanin \& M. Kanin, Rashomon (1959) (play based on the short stories Yabu no Naka and Rashomon by R. Akutagawa).

3. Reagan Nominates Miller, Adkinson as FTC Commissioners, [July-Dec.] Antitrust \& Trade Reg. Rep. (BNA) No. 1021, at A-1, 2 (July 2, 1981).

4. The Commission approves or disapproves initiatives by the bureau chiefs. Commissioners' indications of what complaints they want to see often influence the bureau chief's selections. 
priorities. He articulates a vision reflecting the direction in which he proposes to lead the Commission during his tenure. Often that direction is different from the course that had been charted by his predecessor. Indeed, one of Mr. Miller's qualifications for the job was his capacity and determination to lead the FTC sharply away from the course that had been charted by his predecessor, Michael Pertschuk. ${ }^{5}$

Section II of this article examines the political environment at the time of Chairman Miller's appointment as chairman and sets forth his general approach to both competition and consumer protection issues as articulated by him upon assuming the leadership of the Commission and throughout his tenure. Section III discusses three cases decided by a divided FTC; Mr. Miller's majority or dissenting opinion is compared with the opposing opinion of a colleague, and the extent to which "correct" economics has driven the outcome is explored. Finally, some inferences are drawn and some conclusions are reached regarding the significance of Mr. Miller's jurisprudence. In sum, this article is a lesson on the indeterminacy of economics and the vital role played in economic judicial decisionmaking by personal visions of the world and how it should be.

\section{II}

\section{Pertschuk and Miller: Where They Stand}

The selection of James C. Miller, III, to lead the FTC can be understood only in the context of the prior administration; any discussion must begin with the presidential election of 1976, in which Jimmy Carter was elected President on a platform that stressed human values, civil rights, and opportunities for the "little" person and the underdog. He appointed as his FTC Chairman Michael Pertschuk, a public interest lawyer and consumer advocate in the tradition of Ralph Nader. ${ }^{6}$

The FTC is charged with protecting the public against "deceptive acts and practices," "unfair trade practices," and "unfair methods of competition."7 To carry out this mandate, Pertschuk pursued an activist agenda. Worried that television advertising directed at young children exploited and abused them by programming them to demand excessive sugar-coated products

5. See Reagan Nominates Miller, Adkinson as FTC Commissioners, supra note 3. See also Government Leaders Forecast Less Regulation, Greater Role for Self-Regulation by Business, [Jan.-June] Antitrust \&e Trade Reg. Rep. (BNA) No. 10-18, at A-6 (June 11, 1981). See generally A Report Prepared by a Member of the Federal Trade Commission (Pertschuk) together with Comments from other Members of the Commission for the use of the Subcommittee on Oversight and Investigations of the Committee on Energy and Commerce, U.S. House of Representatives (1984) [hereinafter Pertschuk Report].

6. See Pertschuk Wins Senate Confirmation to FTC: Pledges to Seek Ways to Expedite Antitnust Cases, [Jan.Dec.] Antitrust \& Trade Reg. Rep. (BNA) No. 808, at A-25, 26 (Apr. 7, 1977); see also Answers of Michael Pertschuk to Questions of Senate Commerce Committee, [Jan.-Dec.] Antitrust \& Trade Reg. Rep. (BNA) No. 808, at E-1 to 11 (Apr. 7, 1977); Carter to Choose Pertschuk to Head FTC, [Jan.-Dec.] Antitrust \& Trade Reg. Rep. (BNA) No. 803, at A-9 (Mar. 1, 1977); Pertschuk's Nomination as FTC Chairman Sent to Hill; Senate Schedules Hearings, [Jan.-Dec.] Antitrust \& Trade Reg. Rep. (BNA) No. 807, at A-6 (Mar. 29, 1977). See generally M. Pertschuk, Revolt Against Regulation: The Rise and Pause of the Consumer Movement (1982).

7. Federal Trade Commission Act of $1914 \$ 5,15$ U.S.C. $\$ 45$ (1982). 
harmful to their health, he introduced a major initiative for FTC rule making. In addition, he introduced initiatives requiring manufacturers to disclose broadly defined product defects, ${ }^{8}$ requiring used car salespeople to state known defects on a sticker on the car, ${ }^{9}$ and requiring funeral homes to unbundle the price of caskets, burial services, and other services provided, and to give price information on request by telephone. ${ }^{10}$ The above efforts, if fully successful, would have enlarged the "unfairness" and "deception" jurisdiction of the FTC.

Pertschuk's initiatives provoked response. As Pertschuk himself reports, the wrath of the advertising business, the broadcasting industry, the cereal business, product manufacturers, the funeral business, and the used car business came down on the FTC. Business lobbyists stormed Congress to protect their industry's profits. ${ }^{11}$ Others felt that the FTC had intruded too far into personal lives and business autonomy, especially with regard to advertising directed to children. Resentful parents joined forces with sugarcoated cereal producers. On March 1, 1978, the Washington Post carried an editorial entitled: "The FTC as National Nanny."12

The children's television advertising proposal became the Achilles' heel of the Pertschuk Commission, which found itself under siege. Although, as will be seen, Pertschuk was or became an economically sophisticated jurist (while always using different assumptions from Chairman Miller and always concerning himself with wealth distribution as well as resource allocation), the Pertschuk Commission became an easy target for those who, whether for personal profit or personal views, advocated a minimalist FTC.

James C. Miller, III, received a Ph.D. in economics from the University of Virginia in 1969. He taught economics. He served during the Ford Administration as a member of the Regulatory Review Group of the Domestic Council, later as Assistant Director for Government Operations and Research at the Council on Wage and Price Stability, and then as Senior Staff Economist for the Council of Economic Advisors, where he was involved with transportation, antitrust, and regulatory issues. ${ }^{13}$ In 1981, newly elected President Ronald Reagan appointed Miller to the post of Regulatory Affairs Director in the Office of Management and Budget. Reagan chose Miller to

8. See Perlschuk Report, supra note 5, at 96-97; Review of Commissioner Michael Pertschuk's Report (Sept. 21, 1984), reprinted in Pertschuk Report, supra note 5, at 275, 306. For comment on the watering down of the rule, see Consumers Union of U.S., Inc. v. FTC, 1986-2 Trade Cas. \ 67,256 at 61,323-25 (D.C. Cir. 1986) (Wald, J., dissenting).

9. See Pertschuk Report, supra note 5, at 161-63; Review of Commissioner Michael Pertschuk's Report, supra note 6, at 315-16. A weak version of the Used Car Rule was adopted in 1984. The rule does not require disclosure of known defects. Id. For the text of the rule, see FTC's Adoption of Regulation Governing Sales of Used Cars, 47 Antitrust \& Trade Reg. Rep. (BNA) No. 1191 at 935 (Nov. 22, 1984).

10. See Pertschuk Report, supra note 5, at 141, 157-59; Review of Commissioner Michael Pertschuk's Report, supra note 8, at 317. The Funeral Rule was adopted in 1981, Chairman Miller dissenting. $I d$.

11. M. Pertschux, supra note 6 , at 69-117.

12. The FTC as National Nanny, Wash. Post, Mar. 1, 1978, at A22, col. 1.

13. Reagan Nominates Miller, Adkinson as FTC Commissioners, supra note 3, at A-1. 
lead the transition team for the Federal Trade Commission-a team that was charged with formulating recommendations for the FTC's direction. After studying the issues and options, the team recommended sending the FTC in "a new direction" and cutting the budget by twenty-five percent. ${ }^{14}$ The new direction recommended by the team was away from the "National Nanny" approach, away from cases based on "social theories," and towards a regime in which there would be "more volunteerism," more private initiative and self-regulation, less protection of consumers and more information, thereby allowing consumers to make their own choices. ${ }^{15}$

By the time President Reagan nominated James C. Miller, III, for membership on the Federal Trade Commission and then appointed him Chairman, ${ }^{16}$ Miller's views of political economy and law and society were well known. Miller affirmed that he would pursue "the things the President stands for"- -expanding the size of the pie and shrinking the "cost of intrusion into personal lives." 17 In public addresses, Miller took a stand against established antitrust jurisprudence, including the per se rule against resale price maintenance and interpretations of the merger law, and he announced that consumers should have the right to buy defective products, to pay less, and to take greater risks. ${ }^{18}$

Each spring, the Antitrust Section of the American Bar Association holds an annual meeting. Featured each year is a report from official Washington. Traditionally, the Chairman of the Federal Trade Commission and the Assistant Attorney General in Charge of the Antitrust Division give a short presentation followed by questions from a panel. Beginning with the spring meeting of 1982, Mr. Miller appeared and gave his views. Questioned about influences on his antitrust thinking, Chairman Miller said that he was most influenced by Robert Bork and Richard Posner, among the lawyers. Among the economists who influenced him, Miller named "George Stigler, Yale Brozen, Harold Demsetz and several [others] who I think have been associated with what is called the 'Chicago School.'"'19

14. Id.

15. Government Leaders Forecast Less Regulation, Greater Role for Self-Regulation by Business, [Jan.-June] Antitrust \& Trade Reg. Rep. (BNA) No. 1018, at A-6, 7 (June 11, 1981).

16. Miller served as Chairman of the FTC from 1981 to 1985 , when he became Director of the Office of Management and Budget, in which capacity he now serves.

17. Reagan Nominates Miller, Adkinson as FTC Commissioners, supra note 3, at A-1. During Miller's confirmation hearings, his critics expressed alarm. Senator Slade Gorton, a Republican from Washington, said that the Administration "appears to be sending signals to the business community that it does not agree with some established antitrust laws." He and others stated that antitrust law has been historically concerned with values other than economic efficiency. Senator John Danforth, Republican from Missouri, suggested that "[d]eregulation should bring more, not less, antitrust enforcement," and Senator Arlen Specter, Republican from Pennsylvania, feared that Miller's commitment to reducing funding for the FTC's antitrust arm "may be an indirect way of phasing [it] out . . . " Miller Gains Confirmation to FTC; Senators Attack Enforcement Program, [July-Dec.] Antitrust \& Trade Reg. Rep. (BNA) No. 1032, at A-1 (Sept. 24, 1981).

18. See Pertschuk Report, supra note 5, at 98. See also Transition Report, 127 Cong. Rec. S10164 (1981)

19. Interview with James C. Miller, III, 51 ANTITRust L.J. 3, 9 (1982) [hereinafter Miller Interview]. Mr. Miller later further identified himself with the Chicago School, noting that most Chicago School adherents, "as a normative matter .. . placed greater emphasis on economic efficiency and consumer 
When asked what cases his Commission would bring, Mr. Miller pledged that he would not bring actions that did not promise to increase economic efficiency. ${ }^{20}$ He used interchangeably the expressions "efficient," "procompetitive," and "advancing consumer welfare." 21 Miller suggested that, not being a lawyer, he was not fully conversant with the law.22 He did, however, give his views on some principles of law. When asked about the costs or benefits of resale price maintenance, he identified the facilitation of horizontal collusion as a possible harm, but he suggested that resale price maintenance was more likely to have the "beneficial" effect of preventing discounters from free riding on point-of-sale service provided by higherpriced resellers. ${ }^{23}$

When asked about the Robinson-Patman Act, which prohibits selling the same good at different prices where doing so may lessen competition, $\mathrm{Mr}$. Miller said he feared that the Act might be used to prevent efficiency by preventing price competition. ${ }^{24}$ As for merger law, Miller expressed the view that increased concentration does not support an inference of lessened competition and he said he was "really very concerned about using simple concentration indexes as even a prima facie basis for whether a law violation has occurred." 25 On predatory pricing, Miller voiced "considerable suspicion" about claims that it exists. ${ }^{26}$ " $[E]$ specially . . . with the absence of entry barriers," Miller said, "it just doesn't make sense for a firm to engage in that kind of behavior. I am just greatly suspicious, so I guess I would require a great deal more evidence than probably the ordinary person." 27

Chairman Miller identified horizontal collusion (price fixing by competitors) as the restraint that would be the principal concern of the agency. He noted that governmental restraints on private business freedom concerned him more than restraints by private parties. "[Government-

welfare . . . as opposed to 'fairness' or protection of small business." He asserted that Chicago School members have "cast doubt" on correlations between concentration and profitability and therefore on whether noncompetitive performance is likely to result from high concentration, and he declared that Chicago has won the "intellectual war." Id. at 5, 8.

20. Id. at 5. Miller later said that the FTC will "bring cases only when we have both a legal and economic case." Id. at 11 . He assumed that if any given prosecution would not increase efficiency, it would decrease efficiency, for in the next sentence he said: "I fail to see, for example, how it could be in the public interest for us to bring cases that harm competition or consumers." Id. at 11 .

21. Id. at $3,5,18,19$.

22. Id. at $19-20$.

23. Id. at 8,19 .

24. Id. at 7 .

25. Id. at 16. Chief of the Bureau of Economics, Robert Tollison, later said that he would like to conduct "a natural experiment in the economy" where one would allow almost all mergers to go through. "You would allow a lot of people to put their money on the line, and we'll see what happens .... Then, if there are anticompetitive problems, we can try to unscramble the eggs." Interview with Robert D. Tollison, 43 Antitrust \& Trade Reg. Rep. (BNA) No. 1083 at 609, 612 (Sept. 30, 1982).

26. Miller Interview, supra note 19 , at 20.

27. Id. at 20. 
imposed] restraints may be more damaging than their private counterparts since they are likely to break down less often and less quickly," he said. ${ }^{28}$

At the ABA's spring meeting of 1983, Chairman Miller developed in detail his antipathy toward government intervention into the marketplace ${ }^{29}$ and he expressed a sense of disdain for statutes, which he saw as special interest bargains that take from the many and give to the undeserving few. ${ }^{30}$ Miller also denounced domestic industries' seeking government intervention to protect them against low-priced overseas rivals, and he likewise denounced industrial policy initiatives that empower Government to bet on winners and rescue losers. $^{31}$ He cautioned generally against regulation in the name of consumer protection, in the following words:

Regulation is often demanded by those who see the market system as inherently "unfair." According to their model, consumers and producers are locked in a zerosum game, with regulation needed to right the balance in favor of consumers. But the Commission's antitrust and consumer protection experience, coupled with its growing appreciation for their microeconomic foundations, refutes the basic tenets of this view. $^{32}$

Miller's antipathy to local government regulation ultimately led the Commission to sue cities in an attempt to invalidate their taxi regulations. ${ }^{33}$ At the ABA's 1985 spring meeting, Miller defended his use of FTC resources to bring these suits. He had just charged his predecessor, Pertschuk, with "Star Trek law enforcement," and his panel of questioners wondered aloud whether Miller's attack on local regulation was not equally unorthodox. Miller defended his Commission's suits against the cities. He said that Pertschuk's initiatives were protectionist and would hurt consumers; but his would help consumers. ${ }^{34}$

Miller rounded out the picture of himself as an individual bent on increasing allocative efficiency and disregarding equity-even the equity concerns that underpin the law. In the context of consumer protection, Miller indicated his discomfort with applying an act that prohibited "unfair . . . practices"35 (although the Commission was charged with enforcing that law).

28. Id. at 7; see also 60 Minutes with James C. Miller, III, 54 ANTrTRUst L.J. 155, 163-65 (1985) [hereinafter 60 Minutes with Miller].

29. 60 Minutes with Miller at 158. Miller took pride in the fact that "the Reagan Revolution" had dramatically reduced government intrusion.

30. Chairman Miller invoked James Madison's principle from The Federalist No. 62: "This is a state of things in which it may be said with some truth that laws are made for the few, not for the many." Miller Interview, supra note 19, at 5.

31. Id. at 6-8. See In re The City of New Orleans, 105 F.T.C. 1 (1984) (order withdrawing complaint); In re The City of Minneapolis, 105 F.T.C. 304 (1984) (order withdrawing complaint).

32. Id. at 5-6.

33. "Chicago School" Catches a Taxi: FTC Shifting Activity from Big Business to Novel Areas, Wash. Post, June 17, 1984, at G1, col. 1. The suits were withdrawn only after the cities got clear state authorization to limit entry, thus assuring that the regulation was protected by the state action exemption from the antitrust laws.

34. 60 Minutes with Miller, supra note 28 , at 171 .

35. Miller Interview, supra note 19, at 12-13. Miller does not believe in a "fairness" standard because he thinks attempts to apply a fairness principle (e.g., special concern for the underdog or for the trusting and exploitable consumer) undermine attempts to achieve efficiency, and that an efficiency standard advances the public interest. Miller translated his discomfort into a statement 
In the context of merger enforcement, Miller was asked about the role of wealth transfers from consumers to producers. Would he challenge a merger that would raise prices to consumers but benefit producers, where producers would gain as much as, or more than, the consumers would lose? Miller answered that wealth transfers are irrelevant to antitrust analysis; that the task of the antitrust prosecutor and judge is only to estimate whether and to what extent a merger will produce aggregate allocative efficiency losses. If producers would gain at least as much as consumers would lose by a transfer of wealth from consumers to producers, there would be no allocative efficiency loss, and he would not sue. He added "incidentally" that in his view allocative efficiency losses due even to monopoly "appear to be relatively small,"36 thus suggesting that even monopolistic mergers were not clear targets of his enforcement attentions. Miller said:

I admit the Sherman Act and other federal antitrust statutes were driven in part by concerns over equity. . . . But, while I can understand reasonably well the efficiency ramifications of a proposed merger or other kind of business practice, I do not think I or anyone else is trained to know whether the transfer of money from one owner to another in a merger transaction is appropriate or inappropriate. Those kinds of questions are most appropriately addressed by elected officials, not appointed ones. [T] hat kind of equity consideration [transfer of wealth from consumers to producers] is absolutely irrelevant to antitrust. ${ }^{37}$

Finally, Chairman Miller associated a society that protects efficiency with a politically free society. He asserted that our competition system combined with laws that proscribe only inefficient transactions "affects not only our economic well-being, but our basic liberties."38 "Eternal vigilance [to protect this system] is the price of liberty," he said. ${ }^{39}$

Chairman Miller is a Chicago School economist. He believes that market forces are robust and market power is hard to get. He accepts competition as the rule of trade but defines competition in terms of efficiency and assumes that what businesses do is efficient. He views government intervention as the enemy of efficiency. He views nonefficiency values as a drain on efficiency, and he reads out of a statute expressly concerned with fairness even the equity

that he would not know how to achieve equity. See infra quotation in text accompanying note 33 . To advance his view of the public interest, Miller sought to transform the statute's prohibition of deception (which is frequently commensurate with "unfairness") into a standard compatible with allocative efficiency. Id. at 13. For an example, see Miller's proposal for a statutory amendment that would narrowly define the term "deceptive practices" to include only deception to consumers "acting reasonably," would exclude deceptive opinions, and would require evidence that consumers will be harmed. By this means, deceptive statements regarding inexpensive products that consumers purchase often and easily would be put beyond the reach of the law, since reasonable consumers should be able to evaluate such products for themselves. Id. See also Hearings on Fair Practices in Automotive Products Act Before the Subcomm. on Commerce, Transportation and Tourism, of the House Comm. on Energy and Commerce, 97th Cong., 2d Sess. 12 (1982). Congress did not amend the Act, but the Commission adopted the proposed standard in a policy statement. Commission Statement, Oct. 21, 1983.

36. 60 Minutes with Miller, supra note 28 , at 172 . Miller also noted that monopoly may breed less efficient ways of production and that this is another cost of monopoly. Id.

37. Id. at 173 .

38. Miller Interview, supra note 19 , at 13.

39. Id. at 5 . 
concerns that account for the law's existence. He equates laissez faire, limited by no more than minimal antitrust intervention and virtually no regulatory intervention, ${ }^{40}$ with political freedom. ${ }^{41}$ And he is willing to expand the traditional sphere of FTC activity in order to bring efficiency and "freedom" to local citizens. James C. Miller, III, was a brilliant choice to lead the Reagan Revolution at the FTC. ${ }^{42}$

\section{III}

\section{Selected Decisions in the Context of Evolving LaW AND Policy}

The following is an analysis of three selected cases in which there was at least one dissenting opinion and in which Chairman Miller wrote one of the majority or dissenting opinions. Each case treats a different kind of restraint: vertical restraints (Russell Stover) ${ }^{43}$ oligopoly behavior (Ethyl) ${ }^{44}$ and joint ventures (General Motors-Toyota). ${ }^{45}$ After reviewing the legal and economic background and the reasoning and outcome of Chairman Miller's opinion and the opposing opinion in each case, I seek to determine whether the outcome was dictated by economics and to evaluate the importance of sound economic analysis to the outcome of the case.

Although I did not search for cases in which the opposing opinions were written by Pertschuk and by Miller, the three cases meet this description. This fortuity provides an additional benefit. Pertschuk is the model of an individual whose value system is driven by concern for the underdog, a desire to protect those without power from exploitation and abuse, and a belief that only the government can right the imbalances caused and perpetuated by the power of big business. Miller is the model of an individual who believes that merit succeeds, that there are no significant private barriers to opportunity and success, that the government is the enemy of the best, and that

40. Antitrust intervention is designed to remove private barriers to effective competition. Regulation involves government command, such as: Sellers of sugar-coated foods may not direct advertisements to children.

41. For similar comparisons, see M. Friedman, Free to Choose (1980); A. Rand, Atlas Shrugged (1957); and F. Hayek, The Road to Serfoom (1944). Friedman, Rand, and Hayek similarly link minimal government with freedom.

42. In this article, I do not argue the merits of various conceptions of appropriate antitrust law. Elsewhere, I have noted that contemporary economic authorities support different visions of the competition system, including the one that is held by Mr. Miller and one that is quite different from Mr. Miller's. I have shown that the antitrust laws were not driven by an effort to increase allocative efficiency in the sense used by Mr. Miller, and I have argued that concerns for equity, opportunity, and process are embedded in the antitrust laws in ways harmonious with consumers' interests and have produced antitrust rules understandable to business. See Fox. The Politics of Law and Economics in Judicial Decision Making: Antitrust as a Window, 61 N.Y.U.L. REV. 544 (1986); Fox, The Modernization of Antitrust: A New Equilibrium, 66 Cornell L. Rev. 1140 (1981).

43. See Russell Stover Candies, Inc., 100 F.T.C. 1, 50 (1982) (Miller, dissenting), rev'd, 718 F.2d 256 (8th Cir. 1983) (reversed on grounds that there was not sufficient coercion to support the finding of a combination).

44. Ethyl Corp., [1979-1983 Transfer Binder] Trade Reg. Rep. (CCH) ף 22,003 (Mar. 22, 1983), rev'd, Ethyl Corp. v. FTC, 1984-1 Trade Cas. (CCH) I 64,881 (2d Cir. 1984).

45. FTC's Proposed Consent Order on GM-Toyota Joint Venture, 46 Antitrust \& Trade Reg. Rep. (BNA) No. 1146 at 42 (Jan. 5, 1984) [hereinafter Proposed Consent Order]. 
government intervention protects the inefficient and makes all (but the undeserving) worse off. A major question posed by the use of economics in judicial decision making is: How does the judge's value system and world view influence the judge's choices when legal questions involve economic questions, material facts are ambiguous, and economics is indeterminate? A study of the Miller and Pertschuk opinions, side by side, gives some insight.

\section{A. Vertical Restraints-Resale Price Maintenance-Russell Stover}

The Commission's case load, unlike the case load that confronts a federal judge, is developed in view of a need or mission to refine the law as well as to enforce it. The complaint in Russell Stover was a result of a perceived mission to expand the law to protect consumers from resale price maintenance (RPM). The Commission charged Russell Stover, a leading producer of chocolate candies, with maintaining resale prices by a system that fell short of the traditional "combination" in restraint of trade.

Contracts or combinations to maintain resale prices are illegal per se under section 1 of the Sherman Act. 6 By traditional interpretations such combinations are therefore illegal per se under section 5 of the Federal Trade Commission Act, which prohibits unfair methods of competition and is construed to prohibit incipient Sherman Act violations. ${ }^{47}$ A daunting question has been and is: What conduct constitutes a "combination" sufficient to bring activity under section 1 scrutiny and thereby expose a firm to the per se rule? 48

The relevant line of cases began to unfold in 1919, when the Supreme Court decided United States $v$. Colgate. ${ }^{49}$ An indictment had charged Colgate with urging its distributors to adhere to suggested resale prices, with keeping lists of dealers suspended for noncompliance, and with obtaining promises from some dealers that they would comply. The district court interpreted the indictment as not alleging an agreement and the Supreme Court considered itself bound by this interpretation. The Supreme Court affirmed dismissal of the indictment. It declared that, absent a purpose to create or maintain a monopoly, a manufacturer, acting alone, is free to choose the parties with whom it will deal.

In subsequent years, Colgate was deeply eroded by Supreme Court case law broadly defining "contract or combination" for purposes of section 1. In 1960, in United States v. Parke, Davis $\mathcal{E}^{2}$ Company, ${ }^{50}$ the Supreme Court declared that an unlawful combination arises not only from an express or an implied agreement. In dictum the Court said: "[A] combination is also organized if the producer secures adherence to his suggested prices by means which go

46. 15 U.S.C. $\S 1$ (1982). See Monsanto Co. v. Spray-Rite Serv. Corp., 465 U.S. 752, 761 (1984); Dr. Miles Medical Co. v. John D. Park \& Sons Co., 220 U.S. 373 (1911).

47. 15 U.S.C. \& 45(a)(6) (1982). See FTC v. Sperry \& Hutchinson Co., 405 U.S. 233, 235 (1973).

48. "Thereby" does not necessarily follow in logic, but it has followed in law. Chairman Miller has challenged the connection. See infra notes $61-63$ and accompanying text.

49. 250 U.S. 300 (1919).

50. 362 U.S. 29 (1960). 
beyond his mere declination to sell to a customer who will not observe his announced policy."51 Parke, Davis and related authorities gave rise to the claim (and to standard legal advice) that Colgate was dead, not because a pure unilateral refusal to deal with a price cutter was unlawful, but because an announced policy of not dealing with price cutters was so dangerously likely to spill over into a combination among the manufacturer and its nondiscounting dealers that the price of trying to walk the thin line was too high. ${ }^{52}$ Meanwhile, the 1960's saw a rapid growth of mass discounting, and in the 1970's there was strong public support for the freedom to discount. The public sentiment was reflected in the repeal, in 1975, of the federal authorization for state fair trade laws. ${ }^{53}$

In 1980, by authorizing the complaint against Russell Stover, the FTC decided to test the viability of the Park, Davis dictum. It was commonly understood that the effort behind the Russell Stover complaint was to enlarge the coverage of section 1 of the Sherman Act, so that a seller's well articulated and pervasive system both designed to maintain and effective in maintaining resale prices would be illegal, and legality would not hinge on the technicality of whether specific contracts could be found. The effort was, of course, based on the view that RPM hurts consumers.

Thus, the FTC sued Russell Stover Candies, one of the largest makers of boxed chocolates in the country. According to stipulated facts, Russell Stover suggested resale prices to its retailers and announced to the retailers in advance that it would refuse to sell to retailers who sold at less than the designated prices or who led Russell Stover to believe that they would do so; the announced policy induced $94.4 \%$ compliance with the price list, including compliance by retailers who wanted to sell at lower prices but refrained from doing so solely to avoid termination. ${ }^{54}$

The complaint alleged a violation of section 1 of the Sherman Act and therefore a violation of section 5 of the Federal Trade Commission Act. ${ }^{55}$ It did not allege, as it might have done, that the Russell Stover system was an unfair method of competition and therefore independently a violation of section 5 of the Federal Trade Commission Act. The staff and Commission, or some of the members, hoped to sweep more broadly.

Between the time the case was filed and the time it came before the FTC, several things happened. The health of the U.S. economy deteriorated. People blamed the plight of business on "too much" government. They wanted a change and elected Ronald Reagan President. President Reagan

51. Id. at 43 .

52. See Pitofsky, Is the Colgate Doctrine Dead? Affrmative of the Debate, 37 AnTITrust L.J. 772 (1968).

53. See House Comm. on the Judiciary, Vertical Restraints Guidelines Resolution, H.R. Doc. No. 99-399, 99th Cong., lst Sess. $7-8$ (1985) [hereinafter House RePORT ON VERTICAL. RESTRAINTS].

54. Russell Stover Candies, Inc., 100 F.T.C. 1, 18 (1982) (Miller, dissenting).

55. The Federal Trade Commission is not empowered to enforce the Sherman Act as such, but since violations of the Sherman Act would also be violations of the more expansive Federal Trade Commission Act, it has the power to order abandonment of conduct that offends the Sherman Act. 
replaced FTC head, activist, populist, humanist Michael Pertschuk with noninterventionist James Miller.

Economic arguments compatible with less government (while known for many years) began to command respect. These included the claim that if a producer opts for an RPM system, the most likely explanation is that consumers want more service and the producer therefore wants the retailer to provide more service; that a higher price will induce retailers to compete to provide that service, and that, conversely, freedom to discount will induce opportunist resellers to free ride on the services provided by nondiscounters and will thus induce the service providers to degrade quality, all to the harm of consumers. ${ }^{56}$

Against this background, the Commission-now comprised of a somewhat different cast of commissioners-decided Russell Stover. The Commission's opinion was written by Commissioner (former Chairman) Pertschuk, joined by Commissioner Bailey. Commissioner Clanton concurred. Chairman Miller dissented. The principal question addressed was whether Russell Stover's RPM system was based on contracts or combinations. The Commission majority held that it was. The Commission found that each time a retailer unwillingly complied with the designated prices-that is, each time the retailer refrained from discounting only to avoid termination-a combination arose. Russell Stover's system was thus deemed illegal by reason of its "coercion" of unwilling retailers. 57

The majority in Russell Stover took as a given the established per se rule against combinations to fix resale prices. The majority noted but did not address the claim by some that the per se rule should give way to a rule of reason. They observed that combinations to fix resale prices are illegal because of their effect. They noted that the Russell Stover system had exactly the same effect as a system in which the producer secures adherence by threat of cancelling a lease or terminating a franchise, and these latter forms of pressure by a producer had been held by the Supreme Court to constitute sufficient coercion to support a combination. ${ }^{58}$ The Commission held that unwilling adherence resulting from prior communication of a policy to cease supplying price cutters effects a combination. ${ }^{59}$ Therefore the RPM system was carried out pursuant to a combination.

Chairman Miller did not disagree that an antitrust combination was established within the meaning of section 1 of the Sherman Act. He would have found a combination, however, on the basis of the retailers' willing

56. Russell Stover Candies, 100 F.T.C. at 51-53.

Other scholars, however, continue to support the view that resale price maintenance is harmful to consumers. See, e.g., Comanor, Vertical Price-Fixing, Vertical Market Restrictions, and the New Antitrust Policy, 98 Harv. L. Rev. 983 (1985); Pitofsky, In Defense of Discounters: The No-Frills Case for a Per Se Rule Against Vertical Price Fixing, 71 GEo. L.J. 1487 (1983); Scherer, The Economics of Vertical Restraints, in E. Fox \& J. Halverson, supra note 45, at 429. See House Report on Vertical Restraints] supra note 53.

57. Russell Stover Candies, 100 F.T.C. at 51, 52 (Miller, dissenting) (discussing majority opinion).

58. See id. at 34-39 and cases cited therein (opinion of the Commission).

59. Id. at 43 . 
acceptance of the producer's invitation to maintain the designated price. To Miller, coerced RPM is the manufacturer's unilateral act. ${ }^{60}$

But Chairman Miller would not have applied the per se rule. Stating that no competitive harm was shown, he would have dismissed the complaint. Miller reflected only briefly on the possible effects of Stover's distribution system. He assumed that Stover's RPM was procompetitive because of his belief that what business does is probably efficient, collusion is difficult and therefore unlikely, and any other exploitation is "only" a wealth transfer and therefore benign. "Every manufacturer Stover included," he said, "has the incentive to distribute its product in a cost effective, procompetitive manner."61

Both Pertschuk and Miller had little patience with the formalities of the law. Under the formalities of the law, which were perpetuated by the appellate court's later decision reversing the Commission, ${ }^{62}$ RPM is legal or illegal depending upon whether a combination is found and not depending upon whether it hurts competition or consumers. Pertschuk was convinced that RPM hurts consumers or at least does so with such regularity that it merits per se condemnation. Moreover, his value scheme led him to prefer low price to more service in order to benefit the people who cannot afford to pay for service. His definition of competition and consumer benefit includes this preference. ${ }^{63}$ Miller, on the other hand, assumes that if a producer chooses RPM, RPM must be efficient (and therefore, by his definition, procompetitive). Moreover, in his value system a dollar gained by a producer, $\mathrm{a}$ rich consumer, or a poor consumer is all the same.

Neither approach reflects an economic error. The economic analysis, however, depends upon the premises and assumptions used by each, which predictably reflect the analyst's own set of values.

\section{B. Cartel Behavior-Ethyl}

The history of the Ethyl case ${ }^{64}$ antedates the Carter Administration. With the filing of the case in 1974, during the administration of President Ford, the

60. Id. at 51-52 (Miller, dissenting). In his dissent, Miller maintained that "coercion" exists only where the target buckles under to true market power. "Especially where other manufacturers stand ready to distribute comparable products to the retailer [which is presumptively the case, he said], I believe little case can be made for economic coercion simply because one or more manufacturers attach such conditions to the sale of their product." Id. at 52. Miller would draw no inference from the evidence that some retailers wanted to charge low prices but could not do so without risking loss of their business. In Miller's view, the important point was that these and all other Stover dealers must have viewed Stover's terms, including resale price maintenance, as marginally superior to those that could have been obtained from Stover's competitors.

61. Id. at 51 (Miller, dissenting).

62. Russell Stover Candies, Inc. v. FTC, 718 F.2d 256 (8th Cir. 1983).

63. The law itself has a bias in favor of consumers over producers and in favor of low price to consumers. See generally, Fox, The Politics of Law and Economics in Judicial Decision Making: Antitrust as a Window, supra note 42; Fox, The Modernization of Antitrust: A New Equilibrium, supra note 42; Lande, Wealth Transfers as the Original and Primary Concern of Antitrust: The Efficiency Interpretations Challenged, 34 Hastings L.J. 65 (1982).

64. Ethyl Corp., [1979-1983 Transfer Binder] Trade Reg. Rep. (CCH) I 22,003 (Mar. 22, 1983), rev'd sub. nom. Ethyl Corp. v. FTC, 1984-1 Trade Cas. (CCH) ๆ 64,881 (2d Cir. 1984). 
FTC made a major challenge to coordinated behavior of large firms in oligopoly markets. The concerns and initiatives that led to the Ethyl complaint go back more than a decade before it was filed.

In the 1960's and into the 1970's there was a growing concern that leading firms in highly concentrated markets behave cooperatively to the detriment of consumers, costing American consumers some $\$ 90$ billion per year in dollars of that decade. 65 There was a mounting determination to address the problem through law. To some, break-ups held the promise of restoring competition. ${ }^{66}$

For a number of years, the FTC looked for the best case to bring to test the reach of the Federal Trade Commission Act in condemning oligopoly behavior. The Bureau of Competition targeted the cereals industry. ${ }^{67}$ In 1972 , the FTC sued the four significant producers of ready-to-eat cereals. ${ }^{68}$ It alleged that the four firms held more than ninety percent of the market. Kellogg, having forty-five percent, was charged with orchestrating the distribution of valuable shelf space and keeping new entrants out. The big four incumbents were charged with proliferating their brands to fill all niches of consumer demand, with advertising excessively, thus raising entry barriers, and with acquiring small competitors to expand their market control. The FTC's staff estimated that twenty cents of every consumer ready-to-eat cereal dollar went for advertising (which was far beyond what was needed to disseminate information), and that a successful lawsuit against the cereal companies could save American consumers $\$ 150$ to $\$ 250$ million per year. ${ }^{69}$ The theory of the case changed somewhat over time, shifting from interdependence of the cereal companies without conspiracy ("shared monopoly"), to conspiracy based at least on tacit collusion.

The FTC staff sought the break-up of Kellogg, General Foods, and General Mills. It eventually dropped from the case the smaller Quaker Oats. Ultimately, it lost the case before an Administrative Law Judge. ${ }^{70}$ In the wake of Chairman Miller's plea for "a merciful end" to the case (by this time Miller was Chairman), the Director of the Bureau of Competition decided not to appeal, ${ }^{71}$ and the Commission, by a vote of three to one (Pertschuk dissenting), voted not to direct the staff to pursue the appeal. ${ }^{72}$

65. See Ferguson, The Case for Antitrust Suits Against Selected Oligopoly Industries, ANTITRUST L. \& ECON. Rev., Summer 1975, at 26; Mueller, FTC and the Monopoly Problem: Trustbusting a "Revolutionary" Concept in America?, Antitrust L. \& ECon. Rev., Summer 1975, at 9, 11; see also F. Scherer, Industrial. Market Structure and Economic Performance 538-40 (2d ed. 1980).

66. See generally, Ferguson, supra note 65; Mueller, supra note 65.

67. See generally, Wilson, The FTC's Deconcentration Case Against the Breakfast-Cereal Industry: A New "Ballgame" in Antitrust?, Antitrust L. \& Econ. Rev., Summer 1971, at 57.

68. See In re Kellogg Co., [1979-1983 Transfer Binder] Trade Reg. Rep. (CCH) If 21,899 (Jan. 15, 1982) (Pertschuk, Commissioner) (dismissing complaint).

69. See Wilson, supra note 67, at 74-75.

70. See In re Kellogg Co., [1979-1983 Transfer Binder] Trade Reg. Rep. (CCH) ๆ 21,899 (Jan. $15,1982)$.

71. See FTC Seeks More Information on Whether to Review ALJ's Dismissal of Cereal Case, [July-Dec.] Antitrust \& Trade Reg. Rep. (BNA) No. 1045, at A-3 (Dec. 24, 1981).

72. In re Kellogg Co., [1979-1983 Transfer Binder] Trade Reg. Rep. (CCH) ๆ 21,899 (Jan. 15, 1982). 
During the period before and during the cereal case, Justice Department officials expressed similar concerns about concentrated industries. In the late 1960's, the Antitrust Division had reportedly drafted a complaint seeking a break-up of General Motors, ${ }^{73}$ which was never filed. By the mid-1970's, while still concerned with the problem of cooperative behavior, the Division became increasingly concerned that break-ups might entail unacceptable social costs, and it started to explore other solutions to the concentrated industries problem. The Justice Department began to focus on practices among oligopolists that could facilitate cooperative behavior, where conductoriented injunctions alone might improve industry performance. ${ }^{74}$

While pursuing a break-up strategy in the cereals case, the FTC, too, looked for a target industry whose members behaved noncompetively through the unilateral, but interdependent, use of practices that could be enjoined. Its efforts resulted in a suit against the four producers of gasoline additives in the form of lead-based antiknock compounds. At the time of the suit in 1974, Ethyl Corporation, which had been the sole domestic producer of antiknock compounds for more than twenty years, accounted for $33.5 \%$ of the market. Du Pont held $\mathbf{3 8 . 4 \%}$. The only other two producers were PPG, which had more than $16 \%$, and Nalco, which had almost $12 \%$. Environmental protection regulations had contributed to a sharp decline in demand for noknock additives; there was excess capacity, and the industry was moribund. ${ }^{75}$

As for the no-knock additives industry, the FTC staff painted the picture of classic cartel behavior, executed by means of devices that facilitated coordination. It did not allege conspiracy. It asked for relief enjoining the use of these facilitating devices. The Administrative Law Judge upheld the staff. He found unfair methods of competition in violation of section 5 of the Federal Trade Commission Act. ${ }^{76}$ The Commission affirmed, three to one. ${ }^{77}$ Commissioner Pertschuk, joined by Bailey and Clanton, wrote the opinion of the Commission. Chairman Miller dissented.

The opinion of the Commission presented the cartel interpretation: The industry was very highly concentrated. Four firms held one hundred percent. The product was homogenous. Demand was inelastic. There had been no entry of new firms for more than fifteen years and entry was unlikely. Prices were above a competitive level and rising despite sluggish demand. Each industry member quoted prices and sold only on the basis of a delivered price,

73. See Restraints and Monopolies: Justice Dep't Says It Hasn't Decided What To Do, "If Anything," About Auto Industry, [Jan.-Dec.] Antitrust \& Trade Reg. Rep. (BNA) No. 330, at A-13 (Nov. 7, 1967).

74. See Shenefield, Antitrust Division Memorandum on Identification and Challenge of Parallel Pricing Practices in Concentrated Industries, [July-Dec.] Antitrust \& Trade Reg. Rep. (BNA) No. 874, at F-1 (July 27, 1978); United States v. General Elec. Co., 1977-2 Trade Cas. (CCH) ף 61,660 (E.D.Pa. 1977).

75. Ethyl Corp., [1979-1983 Transfer Binder] Trade Reg. Rep. (CCH) ๆ 22,603, at 22,536-37 (Mar. 22, 1983), rev'd sub. nom. Ethyl Corp. v. FTC, 1984-1 Trade Cas. (CCH) $₫$ 64,881 (2d Cir. 1984).

76. Ethyl Corp., [1979-1983 Transfer Binder] Trade Reg. Rep. (CCH) ๆ 21,856 (Aug. 21, 1981), aff'd, [1979-1983 Transfer Binder] Trade Reg. Rep. (CCH) I] 22,003 (Mar. 22, 1983), rev'd sub. nom. Ethyl Corp. v. FTC, 1984-1 Trade Cas. (CCH) I 64,881 (2d Cir. 1984).

77. Ethyl Corp., [1979-1983 Transfer Binder] Trade Reg. Rep. ๆ 22,003, at 22,578. 
even when buyers, including big ones like Exxon, requested quotes F.O.B. Ethyl and Du Pont had most-favored-nations clauses in their standard contract and used most-favored-nations clauses in spot sales, and Nalco often used such clauses, thus promising customers the benefit of the lowest price at which the seller would sell to any other customer. Each respondent contracted to give its customers thirty days' advance notice of any price change, and they frequently gave more than thirty days' notice to the press and to customers.

The facts as accepted by the Administrative Law Judge and the Commission's majority fit the model of a cartel. The delivered price practice would simplify coordination, thereby easing the task of agreeing to a common price, and it would reduce uncertainties about current prices, giving adhering members assurance that the pact was honored. The most-favored-nations clauses would make price reductions (cheating from the cartel price) costly and therefore improbable. The publicized advance notice of price changes over and above the thirty days required by contract would provide a means of notifying cartel members of the new cartel price, inviting their acceptance, and giving them time to equate their prices with the initiator of the change.

The Commission noted that not all factors pointed to cartel behavior. For example, buyers were big and few. There was some price discounting, although rarely by Ethyl and never by Du Pont. All three of the challenged practices had been initiated by Ethyl at the time when it was the only firm in the market. Respondents insisted that their conduct was responsive to consumer demand. For example, respondents argued that sales were made on the basis of delivered prices only because buyers wanted manufacturers to retain title during transportation so that the manufacturers would be liable for any explosion of the gases en route. Nonetheless, the majority, as the Administrative Law Judge, saw the cartel story as the dominant story to be told.

The majority rejected the legal argument that agreement or collusion was a necessary condition to a violation of the Federal Trade Commission Act, which on its face does not require joint action. While mere interdependent, supracompetitive prices would not offend section 5 , the majority said, section 5 is appropriately read to address specific conduct that produces the anticompetitive effects that the Sherman Act was designed to prevent. In so concluding, the Commission cited, among others, Professor (now Judge) Posner: "Economic theory suggests that basing point systems should be enjoined under Section 1 of the Sherman Act regardless of whether there is proof of actual agreement, because the plain purpose of such systems is to foster monopoly pricing.' "78

The Commission found a violation. It entered an order prohibiting use of most-favored-nations clauses by Du Pont and Ethyl, requiring all respondents to allow purchasers an option to buy the antiknock compounds F.O.B., and

78. Id. at 22,532 . 
barring most price announcements in advance of the contractual period provided to customers.

Chairman Miller dissented. He drew entirely different inferences from the facts. He said entry barriers were not high, the product included a service dimension and was therefore not homogenous, price was not the main factor in sales, the demand facing the firms was not inelastic at market price, sales at discounts abounded, and the structural factors suggested that the sellers could not profitably collude because the buyers were big and sophisticated. He drew no negative inference from high concentration, labeling the claim that high concentration signals lack of competition highly debatable. ${ }^{79}$

Chairman Miller accepted respondents' business justification on all points; for example, he found that delivered pricing was maintained to put the risk on the manufacturers and assure the safe handling of the product. While "not necessarily reject[ing] the general concept underlying the new cause of action created by the majority," 80 Miller said that the majority's standard was too inclusive and vague. Miller would condemn facilitating practices in an oligopoly only if respondents offered no legitimate business reason and only if the practices reduced the overall level of competition by reducing "industry output of a truly homogenous product-reductions that could not be remedied either by an existing industry renegade, or by a destabilizing new entrant." 81 His view of the facts in Ethyl did not fit his standard.

The Court of Appeals for the Second Circuit reversed the Commission. ${ }^{82}$ Judge Mansfield, speaking for the majority, accepted Chairman Miller's factual view of the antiknock market and accepted the truth of the business justifications of the respondents. He likewise agreed with Chairman Miller's assessment of the overbreadth of the Commission's standard. The standard is so vague, Judge Mansfield said, "as to permit arbitrary and undue government interference with the reasonable freedom of action that has marked our country's competitive system."83 Absent a tacit agreement, according to Mansfield, a minimum standard for violation would demand at least some indication of oppressiveness, such as evidence of anticompetitive intent or absence of an independent business reason. ${ }^{84}$

The Ethyl case raises two sets of questions. The first set of questions is fact-based: Did the industry members behave cooperatively instead of rivalrously, and would their performance be improved by, for example, an injunction that required respondents to sell F.O.B. on request? The second

79. Id. at $22,562-577$.

80. Id. at 22,562 .

81. Id. at 22,563 .

82. Ethyl Corp. v. FTC, 1984-1 Trade Cas. (CCH) थ 65,881 (2d Cir. 1984).

83. Id. at 67,707 .

84. Judge Lumbard, concurring in part and dissenting in part, noted that courts construe "tacit agreement" broadly and sometimes use anticompetitive effects as a proxy for agreement. He doubted that the use of section 5 to catch facilitating devices would substantially broaden the Commission's power. He noted that section 5 may be a particularly well suited tool, since its application gives rise to no treble damages and no criminal remedies. He would have vacated the order, however, on grounds of insufficiently compelling facts. Id. at 67,711-712. 
set of questions combines facts, economics, and the law: Is law that prohibits conduct that facilitates oligopoly behavior likely to produce more competitive performance by industry members? Or is it likely to be so subjective or misunderstood or misused as to chill competitive behavior?

In Ethyl, Commissioner Pertschuk, with the majority, answered all questions in favor of the intervention. Chairman Miller answered all questions against it. Both made economically sensible statements. Each drew inferences predictable from the world view of each: business gets and keeps market power versus business must please consumers or the market will punish it quickly and surely. ${ }^{85}$

Ethyl was the last of a series of failed attempts by the FTC to expand the law to address oligopoly behavior. Perhaps Ethyl marked the end of an era. If so, this was not because the theory of the case was wrong, ${ }^{86}$ but either because people feared the unbridled power of the FTC-which could after all become the National Nanny-or because they came to view the game as not worth the candle.

The next case that I review occurred in the context of a new era. President Reagan had appointed two new commissioners, Terry Calvani, a law professor with an economic bent and a noninterventionist approach, and George

85. In some instances, Miller and Pertschuk drew different inferences of fact. In other instances, they used different economic conceptions. For example, Miller found low barriers to entry and Pertschuk found high barriers to entry. This is because they defined barriers differently. Miller defined an entry barrier as a high long run cost that entrants must bear in excess of those costs incurred by incumbents. Ethyl Corp., [1979-1983 Transfer Binder] Trade Reg. Rep. (CCH) I 22,003, at 22,571; see also Echlin Mfg. Co., 3 Trade Reg. Rep. (CCH) ๆ 22,268, at 23,300-02 (June 28, 1985) (Douglas, Commissioner) (describing one view of the nature of barriers to entry). Implicitly, Pertschuk used "entry barrier" to mean any hurdle or condition that makes entry unlikely, even in the face of noncompetitive prices of incumbents (i.e., prices higher than cost or higher than what cost would be in a competitive market). See Ethyl Corp., [1979-1983 Transfer Binder] Trade Reg. Rep. (CCH) ๆ 22,003, at 22,536; see also Echlin Mfg. Co., 3 Trade Reg. Rep. (CCH) \ 22,268, at 23,305-07 (June 28, 1985). (Bailey, Commissioner, dissenting, noting that the first definition of entry barriers is associated with Professor George Stigler and the second definition is associated with Professor Joe Bain.)

The definition of an entry barrier is not a "truth" but an instrument. The Bain definition would lead to more and earlier government intervention to protect the public against higher price, even where entry is possible but simply not likely_perhaps because, as in Ethyl, long run prospects are too dim to make entry attractive. The Stigler definition tends toward government abstention. If long run prospects are so dim that no one chooses to enter, Stiglerians would say, there is so little chance that incumbents will produce less than buyers want that we are better off not cranking up the machinery of intervention.

86. The theory of the case-interdependent strategies tending to keep out competition and prop up price-still remains a respected theory, even though the number of industries in which firms could profitably collaborate has probably declined because technological change and world competition are stronger checks on anticompetitive behavior than they were in the past. Especially in declining industries, collaboration may be a more profitable strategy than competition. See Frankena \& Paulter, Antitrust Policy for Declining Industries (Bureau of Economics FTC 1985). For theoretical economic support of the theory of the case, see Hay, Oligopoly, Shared Monopoly and Antitrust Law, 67 Cornell L. Rev. 439, 476-80 (1982); Williamson, Delimiting Antitrust, Geo. L.J. (forthcoming 1987).

An older idea that high concentration automatically produces lessened competition has been discredited. See, e.g., Scherer, On the Current State of Knowledge in Industrial Organization, in 1 Mainstreams in Industrial Organization 215 ( $\mathrm{H}$. de Jong \& W. Shepherd eds. 1986). Nonetheless, as the Reagan Administration Merger Guidelines reflect, high concentration combined with certain other market factors indicates dangers of collusion. In Ethyl, the majority thought that the other factors were present and were dominant; Miller did not. 
Douglas, an economist and co-author with Miller. ${ }^{87}$ Calvani and Douglas, along with Chairman Miller, formed a new majority. The question became not whether the Commission would embark on new initiatives to expand the law, but whether the Commission would enlarge the freedom of firms to do what the law had constrained them from doing.

\section{Joint Ventures-General Motors-Toyota}

The United States automakers were dominant in the world in the 1950's and 1960's. But in the decade beginning in the mid 1970's, they were beset by hard times. The oil crisis shocked the nation into concerns for conservation. Car buyers shifted to smaller, fuel efficient cars, and Congress passed fuel efficiency standards requiring a specified average fuel efficiency for each domestic car manufacturer's output. Meanwhile, the Japanese automakers excelled. They produced a product of higher technical quality than the Americans and they offered attractive small cars at low prices. They soon gained about twenty percent of United States sales.

Chrysler fell into great financial difficulties and was heading towards bankruptcy. Chrysler and the United Auto Workers lobbied the Government for trade restraints to stop the flow of Japanese cars into the United States. After failing to make their case before the International Trade Commission, they enlisted the help of the President to implore the Japanese to cut back on their U.S.-bound exports. In response, the Japanese adopted a Voluntary Restraining Arrangement (VRA). The VRA essentially confined the Japanese to no more than twenty percent of the United States market and raised the cost of imported Japanese cars by about $\$ 1000$ each. Chrysler, meanwhile, was pressing for a government bailout to save it from bankruptcy. Ultimately, moved by the thousands of auto worker jobs at stake, the government came to its aid. ${ }^{88}$ Even under the umbrella of the VRA, the United States auto industry did not meet the challenge of the Japanese. All three United States auto producers had bought some stock in Japanese firms and made some changes based on the Japanese model, but none elevated the quality of their cars to that of their trading partner. ${ }^{89}$

In 1981, General Motors (GM) made an announcement indicating that it would finally learn from the Japanese. Thus, the world's number one automaker, with about forty-four percent of sales in the United States and Canada, announced a proposed joint venture with Toyota, Japan's number one automaker, the third largest auto producer in the world, and GM's biggest rival. The joint venture corporation, New United Motors, planned to produce a car, the TVX (later to be marketed as the Nova), that would be similar to the Toyota Sprinter that was sold in Japan, and was a variation of its Corolla, sold in the United States. The car would be sold by the joint venture to GM for sale through GM dealers. The price of the car to GM would be

87. Douglas was appointed before the FTC decided Ethyl but took no part in the decision.

88. See A. Lowenfeld, Public Controls on International Trade $\$ \$ 5,8$ (1983).

89. Id. 
based on the wholesale prices of a market basket of best-selling subcompacts, of which Toyota's Corolla was the most popular model.

The joint venture would operate at GM's former Freemont plant in California. It would be run by Japanese managers, supervising American workers drawn largely from the former Freemont work force. The high technology parts, including the engine and transmission, would be manufactured by Toyota in Japan and shipped for assembly at the Freemont plant, thereby avoiding the VRA. ${ }^{90}$

The FTC investigated the joint venture. It retained an outside economic expert, John Kwoka. After studying a voluminous investigative record, Professor Kwoka concluded that the joint venture's risks to competition were both "probable and substantial" and that the attributable benefits were "modest and probably largely achievable through competitively innocuous techniques." He advised: "[A] complaint against this joint venture is . . . required."91 The Bureau of Competition, however, under the direction of Timothy Muris, presented a different assessment and recommendation: The joint venture promised substantial net benefits and should proceed under a consent order with few limitations. ${ }^{92}$

A majority of the Commission agreed with Muris. They requested GM and Toyota to accept certain limitations on time period, output, and data exchanges, which the companies said they contemplated all along and to which they readily agreed. Subject to these restrictions, the Commission approved the deal by a vote of three to two, issuing a complaint and a proposed consent order on the same day. ${ }^{93}$

Chairman Miller, with Commissioners Douglas and Calvani, authored the majority statement. Commissioners Pertschuk and Bailey each wrote a separate dissenting statement. The majority began its analysis by emphasizing that "the areas of continued competition between the companies [GM and Toyota] will dwarf the limited area of cooperation."94 It concluded that merger analysis would therefore be inapplicable, and it suggested that concentration measures, which were high, 95 "will be of limited value."96 The majority then summarized its view of the prospective benefits of the joint venture:

90. See Proposed Consent Order, supra note 45, at 42-45.

91. Memorandum from John Kwoka to Edward Glynn, Assistant Director for International Antitrust, Bureau of Competition, FTC, Oct. 3, 1983, at 100.

92. Memorandum from Timothy J. Muris, Director, Bureau of Competition, to the Commission, Dec. 16, 1983, at 41 .

93. See Proposed Consent Order, supra note 45, at 42, 43. The parties agreed to a production cap of 250,000 joint venture cars per year, which would amount to about five pecent of United States small car sales. They agreed to limit the joint venture to a twelve-year period. The parties were permitted to exchange information necessary for the production of joint venture cars but otherwise were not permitted to transfer any information regarding the partners' current or future prices of new automobiles or parts, current or future sales, production forecasts, or marketing plans. Id. at 43.

94. Id. at 54 .

95. According to the Bureau of Competition, the Herfindahls ranged from a low of 1262 (dollar sales, subcompacts) to a high of 2413 (unit sales, all cars). See id. at 51 (Bailey, dissenting).

96. Id. at 54 . 
First, the venture would likely increase the total number of small cars available in America, allowing American consumers greater choice at lower prices despite present restrictions on Japanese imports. Second, the joint venture car will cost less to produce than if GM were forced to rely immediately on other alternatives. Third, and most importantly, the venture offers a valuable opportunity for GM to complete its learning of the more efficient Japanese manufacturing and management methods. If GM can learn how to build significantly lower cost cars, as Japanese producers can now do, it will attempt to implement those lower-cost methods at its other plants. To the extent the Freemont venture can demonstrate successfully that the Japanese system can work in America, the Commission finds that this will lead to the development of a more efficient, more competitive U.S. automobile industry.

Finally, perhaps the most important potential procompetitive benefit from this is the opportunity to increase GM's and ultimately the entire U.S. automobile industry's long-term productive efficiency. GM will acquire hands-on experience of the highly efficient Japanese system of management and manufacturing. Nevertheless, many have asserted that GM does not need Toyota to learn how to lower costs. Although GM no doubt already has learned much about Japanese manufacturing methods, the opportunity to work on a daily basis over several years with Toyota officials will increase GM's knowledge. ${ }^{97}$

As for the joint venture's anticompetitive tendencies, the majority found most possibilities "of low probability or of small magnitude when balanced against the procompetitive benefits of the joint venture."98 The majority thought that the market basket pricing formula, far from being anticompetitive, had a "considerable advantage" over other means of determining the selling price to GM because it would decrease the need to exchange sensitive information. Perhaps most important, the majority did not fear that exchanges of sensitive information would facilitate collusion because it saw market forces as too robust to allow collusion. Thus:

Given the characteristics of the automobile market, it appears that the joint venture will not result in an increased risk of tacit or explicit collusion. Automobiles are highly differentiated in terms of quality, performance, appearance, and durability. The demand for cars shows cyclical swings. Because firms have unequal cost structures, each firm has a different profit-maximizing price. These and other characteristics make a collusive agreement difficult to establish and maintain. ${ }^{99}$

Finally, the statement addressed two areas of competitive concern which, it said, were sufficient to warrant attention. First, expanded production by the joint venture could lead to reduced incentives of GM to produce a small car of its own. This concern was addressed by capping the production of the joint venture. Second, the joint venture created incentives to exchange sensitive competitive information, and " $[u]$ se of the joint venture to facilitate the exchange of such information could significantly increase the likelihood of anticompetitive performance in this industry." 100 This concern was addressed by ordering the parties not to exchange sensitive information that

97. Id. (footnotes omitted).

98. Id.

99. Id. at 55. The statement also considered whether the joint venture would lessen potential competition by deterring Toyota's independent entry into U.S. production, and found it would not. It concluded that Toyota did not contemplate independent entry and moreover that the joint venture might reduce Toyota's apprehensions about independent entry. Id.

100. Id. 
was not reasonably needed for the joint venture. ${ }^{101}$ Thus constrained, the majority believed, the new joint venture would aid the effort to rebuild America's competitiveness.

Commissioners Pertschuk and Bailey had a different view. Pertschuk expressed alarm. "Battalions of neo-classical economists dancing on the head of a pin," he said, "cannot obscure the threat that this marriage of competitors poses to the American consumer . . ."102 Pertschuk described the automobile industry as having been a complacent and bloated oligopoly until the 1970's, when foreign imports pushed it along the road to competitiveness; but the foreign inroads produced the VRA which in turn set back competition and increased the power of GM to set industry prices. According to Pertschuk, a joint venture between GM, the dominant firm, and Toyota, the leading importer, would create such high risks to competition that it should not be allowed absent a substantial showing of procompetitive benefits not available through less anticompetitive alternatives. He would have put GM to this burden at trial. ${ }^{103}$

Pertschuk saw the market as one seriously susceptible to collusion on price and design, especially in light of the VRA. In his view, the joint venture dangerously increased incentives and opportunities to cooperate. The joint venture, he stressed, would not give the consumer anything new. The venture would merely produce an existing car model, most of it to be made in Japan. ${ }^{104}$ He noted that the sources of the Japanese efficiencies were already well known to American firms, who had already adopted the Japanese techniques where practicable, and that the hoped-for efficiencies through a Japanese hands-on environment "argues only for a new [different] venture, not for one with the major Japanese importer." 105

In her separate dissent, Commissioner Bailey added that the joint venture would result in no increased output. As she pointed out, General Motors itself assumed that the joint venture production would be in place of, and not in addition to, products it would otherwise produce. Bailey expressed concern that the joint venture would trigger similar combinations, further increasing opportunities for collusion. Finally, she examined the pricing formula, which correlated the price of the TVX with competitors' prices and which assured that there would be no wholesale price competition between the TVX and the Corolla. In her view, the pricing formula was likely to "infect the prices on other car models, ${ }^{106}$ thus stabilizing the prices of cars along the quality spectrum. To both Pertschuk and Bailey, the limits imposed by the consent decree were cosmetic only. The decree specifically allowed

101. These two concerns are difficult to square with the majority's perception that the automobile market was not susceptible to collusion or to artificial output limitation. Perhaps the limitations were a concession to a public impression, which the majority did not share, that the joint venture would tend to blunt competition between the world's two market leaders.

102. Id. at 48.

103. Id.

104. Id. at $49,50$.

105. Id. at 50 .

106. Id. at 52 . 
exchanges of some sensitive competitive information and would push prices upwards.

It is hard to argue that there was a clearly correct economic answer in General Motors-Toyota. If one believed that a joint venture with Toyota was the most promising means for General Motors to learn, assimilate, and pass on the secrets of the Japanese, the benefits of the venture may be seen to outbalance its costs. Indeed, one who believes that the forces of competition are robust would not see any costs to the American consumer. On the other hand, one who is skeptical of the claim that this joint venture would produce efficiencies not otherwise obtainable, one who is sympathetic to the views that the market is susceptible to collusion and that independent action of major market factors tends to yield more progressiveness than combination, and one who predicts that governmental trade restraints will persist or recur, is likely to foresee that the social costs of the joint venture will overwhelm its possible benefits. Chairman Miller presented the case for the former view; Commissioners Pertschuk and Bailey for the latter. All made economically intelligent statements. But economics does not tell us who is right.

What then drove the choice between issuing a complaint (as Pertschuk and Bailey would have done) or approving the deal with only modest restrictions (as the Commission did)? World views about big business and its power, about consumers and their sovereignty, and about the power of business and the power of government, and which is the more to be feared, determined the positions adopted by the majority and the dissenters.

\section{IV}

\section{CONCLUSION}

James C. Miller, III, is an economically sophisticated individual with, by his own account, Chicago School premises. He assumes that the market is robust, he believes that the consumer is sovereign, and he dislikes government intervention. The cases studied-Russell Stover, Ethyl, and General Motors-Toyota-reveal three sets of observations or conclusions regarding $\mathrm{Mr}$. Miller's jurisprudential role. First, Mr. Miller's knowledge and use of economics raised the level of the economic dialogue at the FTC. Second, political philosophy drives economic analysis. Third, transparency increases understanding. The first proposition speaks for itself. I shall comment on the second and third.

An understanding of the political nature of the FTC chairmanship helps the student of judicial decisionmaking to pierce the myth of the neutral judge applying economic principles dispassionately. Contested antitrust cases normally involve ambiguous facts and indeterminate economics. Each of the three cases studied fits this description. ${ }^{107}$ In each case the judge-

107. I do not claim that economics does not matter or that economics is so widely indeterminate that it is not a useful guide. I do suspect, however, that across the range of antitrust cases that a government agency is likely to bring, at least more often than not there are sound economic observations and arguments to support either side. Within this range, already narrowed by the fact 
commissioner was confronted with difficult questions to which there was no economic consensus. At every turn, Mr. Miller drew the inference against the intervention and Mr. Pertschuk drew the inference for it. This was predictable, wholly apart from any claim that fact finding and economic analysis are consciously result-oriented. As in Rashomon, in the event of ambiguity, one sees what one is predisposed to see.

Mr. Miller will probably be remembered as a Reagan appointee who did his part to help get the government off the back of business. Producing a minimal state is not, however, likely to be the objective of all administrations to come. A future president with a different vision of law and society is likely to appoint an FTC chairman or -woman charged with moving the FTC back somewhat along the continuum towards a larger government role in protecting both consumers and the competitive process.

Finally, transparency is good. We are better off if we can see through economic analysis to the premises that drive it. The FTC stewardship provides us with transparency. Consistent with the policy role he was filling, Chairman Pertschuk wore his premises on his sleeve. Chairman Miller did so, too. Fittingly for the FTC, the Commission provides us with truth in economics.

that the issue in each case is whether the transaction helps or hurts competition, it is not surprising that economics is frequently indeterminate.

When economics is indeterminate, the variations in the economic experts' testimony and conclusions are likely to be explainable by different assumptions, including particular assumptions about how quickly resources are likely to move to the next best profit opportunity. If the economic expert has taken on the mantle of a partisan, she is likely to draw all inferences of fact in favor of her client, and in highly fact-specific cases this phenomenon helps to account for the usual gap between expert witnesses for adverse parties.

At the level of judicial decisionmaking, the principal question is not one of economics at all but one of law. The judge has the duty to apply the law, whether or not the law promotes allocative efficiency. When law itself is indeterminate, the judge may consider the economic impact of the challenged conduct, the probable economic effect of proscribing the challenged conduct, and the norms that are imbedded in the law. See Fox, The Politics of Law and Economics in Judicial Decision Making: Antitrust as a Window, supra note 42. 
